\title{
The Origin of Leprosy in Brazil and its present Situation
}

(Lecture given at the Woman's Club, April 6th, 1936).

H. C. de Souza-Araujo.

History.

When Brazil was discovered leprosy was unknown among our natives. The famous medical report of Dr. G. Pison, published in Holland in 1648, is the proof of such affirmation. Later on many other books regarding our natives have appeared, and in no one is leprosy described among our pure Indian tribes. The Jesuits lived here 210 years (1549-1759), most of them among Indians; they wrote very many books and reports but they never referred to leprosy as being a disease met with among our aboriginals.

From 1917 to 1924 I examined, personally, hundreds of Indians (Guaranys and Caingangs in the South and Tembés and Tymbiras in the North of Brazil, and Navahos in Arizona, U.S.A.), looking for leprosy and never found one case of this malady among them.

The origin of this terrible scourge in Brazil can be traced to the European colonists and African slaves. Without any doubt the Portuguese were the first to introduce the disease here which was very prevalent in Portugal at that time. In France in the 14th and 15th centuries there were very many leper asylums. In the Department of Pas-de-Calais alone there were 237 and in Normandy 218 such institutions. Brittany (Bretagne) was also a great focus of the disease. In these regions of France were recruited most of the mariners who came to Brazil in different expeditions, from 1555 to 1711 , and we believe that among them came many lepers. You must remember, that the old foci of leprosy in Canada originated from French mariners from Normandy.

The Dutch also lived in Brazil by thousands for 30 years (1624 to 1654), and in the 15th and 16th centuries leprosy was also prevalent in Holland. There were 60 leprosariums which began to be closed after the navigation period. In 1614 that at Delft was closed, in 1628 that in the Haag, in 1641 that at Middeeburg, and in 1672 in Leeuwarden, etc. The Dutch people ruled through 300 leagues of our littoral. I believe that they also introduced leprosy cases into the Northern part of Brazil.

On a much larger scale are the African negros responsible for the introduction and dissemination of leprosy in 
Brazil. According to Barao do Rio Branco (Esquisse de l'Histoire du Brésil) Africans were first brought here in 1540 and in 1585 the known population of Brazil was as follows: White people 25,000, Indians 18,500, African slaves 14,000, totalling 57,500. Prof. Fernando Terra says that the British navigators started the introduction of African slaves into Brazil in the year of 1580 . This inhuman commerce lasted until the 4th of September, 1850, when it was definitely prohibited.

The principal ports of importation of negros were Rio de Janeiro, Bahia and Recife, where the disease progressed rapidly. In 1637 the first plea for leprosy control in Rio was made. In 1710 , Rio's population was 60,000 , of which half were negro slaves. In 1849 the population of Rio Municipality (created on August 12th, 1834) attained 266,466 , being 142,403 whites and 124,063 coloured, of which 110,602 were negro slaves. In 1851 the Province of Rio de Janeiro had 556,080 inhabitants, of which 293,554 were slaves! The second report against the dissemination of leprosy here is dated 1696 (Governor Arthur de Sá e Menezes). This showed that the disease was much more prevalent among black and mixed people, than among whites, as proved by the following data :

In Rio from the beginning of the 19th century until 1897 there were interned in the Hospital dos Lazaros 2,090 lepers (Males 1,247, Females 843 ) out of which about $2 / 3$ rds were negros or mulattoes. Of the whites $(1 / 3)$, about a half were Portuguese. In Bahia from 1787 to 1890 were isolated in the Hospital dos Lazaros 1,411 lepers. Out of 1,285 in which races were specified there were: Whites 331, African negros 453, Brazilian negros 194, Mulattoes 337: 984. Three-fourths of these lepers were negros or their close offspring. In Recife (Pernambuco) from 1789 to 1880 there were isolated 1,440 lepers, of which more than two-thirds were coloured people. The recent census of lepers gives for Pernambuco 688 lepers, of which about $70 \%$ are negros or mixed.

In the State of Pará in 1847 there were in the leper Asylum of Tocunduba 70 lepers, of which only five were white. The census of lepers which I organized in Pará and published in 1922 shows that for the total of $1,354,763$, or more than $56 \%$ were coloured people.

F. Terra affirms that since 1600 there were many lepers in the city of Rio. The first cry of alarm of the Municipality is dated 1637, the second 1697 . In 1740 the Municipality asked the Royal Government to build "gafaria " for Rio's 
lepers, which then totalled 300 for little more than 60,000 population.

In 1741 the Governor-General of Rio, Count de Bobadella, (1737 according to Sigaud), concentrated the poor lepers of the City in S. Christovam where he built some huts. After the death of Count de Bobadella (January 1st, 1763), Count da Cunha was nominated Viceroy of Brazil, who, by Royal order moved the lepers from the primitive huts to the Jesuits Convent of S. Christovam, in the same place where exists now the old Hospitam dos Lazaros, maintained by the Brotherhood "Candelaria ". This hospital is now modernized.

Statistics.

There are in Brazil three great foci of leprosy: in the North, from Maranhão to Acre Territory; in the Centre, Minas Geraes; in the South, São Paulo. But, unfortunately, we have lepers in every State and the total is estimated at about thirty thousand, that is about three-quarters per thousand population or 75 lepers per 100,000 inhabitants.

It is true that in many other countries the incidence of leprosy is much higher than in Brazil and the control of it is not so well developed as here, but it is very pitiful that our Federal and State governments have lost so many years without taking any measures of control, which has resulted in the very bad present situation!

\section{Legislation.}

The early legislation against leprosy in Brazil is voluminous and interesting. In 1740 the City Council of Rio (Camara Municipal) alarmed at the prevalence of leprosy in the City, asked, through the Governor of the Capitania, General Gombes Freire de Andrade, the King of Portugal, Dom João V, for control measures. The king nominated a Commission of three court physicians to elaborate a plan of control of the disease in Rio. This was done on January 27th, 1741 and sent to the Governor of Rio with the Royal Order of April 27th, 1744. This ordinance considered leprosy as a contagious disease; regulated the treatment of patients, considering curable those in the early stages; regulated the isolation of the patients in leper asylums separating them according to sex and social conditions; advised the segregation of children from leprous parents, and advised the rigorous selection of African immigrants; advised measures against improper food; remembered the possible confusion of leprosy with syphilis, 
and promulgated very many other wise measures which enhanced the importance of the measure.

On February 17th, 1766, Count da Cunha approved a decree considering compulsory the segregation of all lepers in the Hospital dos Lazaros. With the rigid enforcement of this decree the hospital became overcrowded. In 1787 the Governor of Bahia, Dom Rodrigo José de Menezes inaugurated a second hospital for lepers whose regulations were a model of leprosy legislation. The results of segregation of lepers in Rio and in Bahia were very good.

On May 10th, 1836, the Governor of Pará, Barão de Caçapava, also approved a law against leprosy. If those good laws had been rigidly enforced for the necessary time, the terrible scourge of leprosy would have disappeared from the original foci of colonial times. As the result of a paper read before the National Academy of Medicine in 1838 the control of leprosy was relaxed and the disease increased.

From 1840 to 1920 the leprosy problem was abandoned. In 1921 was created the Federal Bureau of control of Leprosy, in connection with the National Public Health Department. Then a census of lepers was started. The Federal rules of prophylaxis were approved, which included the modern anti-leprotic treatment in dispensaries, the isolation of lepers in domicile, in asylums, in sanatoria and especially in agricultural colonies. The State of S. Paulo adopted the Federal Regulations. We do not need better laws for the control of leprosy, we need decisive action by the Governments-Federal, State and Municipal.

\section{Control.}

The segregation of lepers is the paramount measure against the disease. But we need only to segregate the " open cases", i.e., those with active lesions and expelling bacilli. The "closed cases", i.e., those actually considered as not infectious, may be treated in general hospitals and kept at home under sanitary supervision. For segregation of lepers we have now in Brazil the following institutions, called " Hospital dos Lazaros ", which are leper asylums :

1. In Rio de Janeiro, founded in 1766, with about 100 patients.

2. In Bahia (s. Salvador), founded in 1787 , with 50 beds.

3. In Recife, founded in 1789, with more than 200 beds.

4. In Belem (Para), founded in 1815, with 300 patients.

5. In Sabara (Minas), founded in 1883 , with 70 beds.

6. In Rio Branco (Acre), opened in 1930, with 60 beds.

The following new leprosaria, some of the hospital- 
asylum type, others of the colony type, have been opened more recently and have been increasing in size and in importance.

1. Lazaropolis do Prata (Paraá), the first Brazilian agricultural colony for lepers, founded by me and opened on June 24th, 1924, with 354 patients. Now it has more than 600 patients, and it is being enlarged by the "Liga contra a Lepra do Pará".

2. Leprosario Sao Roque (Parana), opened on October 20th, 1926, now with 400 patients.

3. Asylo-Colo

with 400 patients, now with about 1,200.

4. Hospital-Colonia Curupaity (Rio de Janeiro city), opened on 15th October, 1928, with 50 patients and now with 400 . It is being enlarged to 700 beds. Its founder and director is Dr. Theode Almeida.

5. Leprosario Canafistula (Antonio Diogo, Ceará), opened on August 9th, 1928. Now with 210 patients. Connected with it there is a preventorium for children of leprous parents.

6. Leprosario S. Francisco de Assis (Natal), opened on January 14th, 1929. Now with 100 patients.

7. Leprosario Paricatuba (Belisario Penna, Manáos), opened on July 1st, 1930. Now with more than 300 patients.

8. Sanatorio Padre Bento (S. Paulo city). Leper sanatorium for transient and for good social class lepers, founded by myself and opened on June 5th, 1931. Now much enlarged, with 300 patients.

9. Colonia Santa Izabel (Minas Geraes), inaugurated on December 23rd, 1931, now with about 1,000 patients and being increased to 1,600

10. Asylo-Colonia Pirapitinguy (S. Paulo), opened in 1933. Now with 1,550 patients. This one is the largest and most comfortable in Brazil.

11. Asylo-Colonia Aymorés (Bauru, S. Paulo), opened in 1934. Now with 500 patients.

12. Asylo-Colonia Cocaes (Casa Branca, S. Paulo), opened in 1934. Now with 600 patients.

At present Sao Paulo alone has about 5,000 lepers isolated, without any help of the Federal Government.

13. Colonia Itanhenga (Espirito Santo), inaugurated on May 23rd, 1935. Capacity for 300 patients.

The National plan for the control of leprosy organized by me in 1933 is being studied by the Government to be put in execution.

In the control of leprosy in Brazil the women's cooperation has been of great importance. It is enough to remind you of the ladies Alice Tibiriçá and Margarida Galvão of S. Paulo, and Eunice Weaver of Minas Geraes, among others, who have done very much for the relief of our poor lepers. 